University of Nebraska - Lincoln

DigitalCommons@University of Nebraska - Lincoln

Sociology Department, Faculty Publications

Sociology, Department of

2004

Job Exit Queues: Corporate Mergers and Gender Inequality

Terceira A. Berdahl

University of Nebraska-Lincoln

Helen A. Moore

University of Nebraska-Lincoln, hmoore1@unl.edu

Follow this and additional works at: https://digitalcommons.unl.edu/sociologyfacpub

Part of the Sociology Commons

Berdahl, Terceira A. and Moore, Helen A., "Job Exit Queues: Corporate Mergers and Gender Inequality" (2004). Sociology Department, Faculty Publications. 117.

https://digitalcommons.unl.edu/sociologyfacpub/117

This Article is brought to you for free and open access by the Sociology, Department of at DigitalCommons@University of Nebraska - Lincoln. It has been accepted for inclusion in Sociology Department, Faculty Publications by an authorized administrator of DigitalCommons@University of Nebraska - Lincoln. 
Published in Equal Opportunities International 23 (2004), pp. 45-66.

Copyright () 2004 Emerald Group Publishing Limited. Used by permission.

\title{
Job Exit Queues: Corporate Mergers and Gender Inequality
}

\author{
Terceira A. Berdahl and Helen A. Moore
}

\begin{abstract}
Purpose: to explore the experiences of employees in a local bank merger in the United States and examine the concept of job exit queues. We introduce the concept of a job exit queue, which describes how workers position themselves or are positioned by employers to leave jobs and enter new jobs following the announcement of a corporate merger.

Design/methodology/approach: Qualitative interviews with mid-level managers, technical specialists and low status workers during the sale and merger process were conducted and coded thematically. We explore: 1) how workers and managers describe the job search as an "opportunity" or as a recurring cycle of low-wage, high-turnover work and 2) how severance packages structure the job exit queue to meet corporate needs.

Findings: The role of severance pay is pivotal in understanding women's and men's job relations to job exit queues. We conclude that employers create job exit queues, placing low status workers and mid-level women managers with less formal education at a disadvantage in re-employment.

Value: This paper contributes a new concept "job exit queue" to the research and theory on workplace diversity, gender inequality, and queuing theories.
\end{abstract}

Keywords: economic restructuring, downsizing, queuing theory, gender inequality

\section{Introduction}

Researchers identify factors in the traditional patterns of hiring in the United States in which employers privilege (white) men in hiring and promotion processes. Reskin and Roos (1990) argue that employers then move down the labor queue to women and minorities, until their employment needs are met (Roos and Gatta 1999). These overall patterns of job segregation by sex have meant lower prestige and lower wages for women (Padavic and Reskin 2002, Bielby and Baron 1986). Work organizations typically display gender segregation patterns in which women are unequally distributed both vertically and horizontally and are treated unequally in rewards and advancement (Stover 1996). In this paper we argue that not only are recruitment and distribution patterns gendered, but so too are the exit patterns during corporate mergers and restructuring.

Terceira A. Berdahl is a doctoral candidate in the Sociology department at the University of NebraskaLincoln. Her areas of research specialty are social stratification (race, class, and gender inequality), workplace and health outcomes, and quantitative research methods. Her work has been published in the Journal of Contemporary Criminal Justice, Social Science Research, and the Journal of Adolescent Health.

Helen A. Moore is Professor of Sociology at the University of Nebraska-Lincoln and has served as Chair of the Department of Sociology and Director of the Women's Studies Program. She received her $\mathrm{Ph}$.D. from the University of California, Riverside in 1979, and her areas of research focus on stratification and inequality, and the sociology of education. Both authors can be contacted at: University of Nebraska-Lincoln, 715 Oldfather Hall, Lincoln, NE 68588-0324 
Sociological analyses of work also highlight job loss and insecurity during local economic fluctuations and globalization pressures (Wallace 1998; Tienda, Smith, and Ortiz 1987, Harrison and Bluestone 198 8). As employers destabilize the local job market through corporate mergers and job restructuring, workers respond from privileged or constrained positions to a shifting employment landscape (Spalter-Roth and Deitch 1999, Browne, Hewitt, Twiggs, and Green 2001). Earlier studies have focused on the significance of economic restructuring for workers in manufacturing sectors of the U.S. economy in the 1980s (Milkman 1997). Today, this restructuring has expanded to service sector jobs where women are concentrated (Burke and Greenglass 2001).

We are particularly interested in the ways that women workers are constrained not only by these larger economic patterns of downsizing, but also by the variable vulnerabilities of workers, both women and men, in a female-dominated sector of the banking industry. We analyze the pivotal role of severance packages during workplace restructuring and the gendered patterns that link these to job search strategies. We extend queuing theory (Reskin and Roos 1990) by applying it to the process of job loss.

Our qualitative research project depicts the on-going employment conditions of 19 workers caught in a local merger and downsizing process at a family-owned Midwestern bank in the United States. Their experiences reflect these larger economic shifts, illuminating how workers are caught in a gender-segregated work sector in the banking industry. We apply queuing theory (Reskin and Roos 1990) to the prolonged job insecurity and job-leaving process following the announcement of a corporate merger. We demonstrate how plans for future employment are linked to class and gender inequality through "job exit queues." Workers with the most resources (human capital, social networks, job status or prestige) enter the job exit queue first. Low-skilled workers and women generally enter the job exit queue later and voice many concerns regarding post-displacement employment. Severance packages were used by the employer to entice workers to stay, even though the terms and requirements for receiving benefits were ambiguous and changed several times as the company switched ownership twice.

\section{Literature Review}

Banking is an excellent case study of a service industry that is feminized and undergoing extensive restructuring. Reskin and Roos (1987) highlight a shift in banking from a male dominated to a female dominated field in the 1980s, and also note research findings that underscore the marginal positions of women entering into banking work. Many women work in deskilled data entry positions with few opportunities for career advancement. Women managers are segregated into smaller branches away from the central locations "where significant decisions are made and important contacts that facilitate career progress nurtured" (Reskin and Roos 1987, p. 12). They conclude that women workers are physically and functionally removed from the power centers of decision-making (Reskin and Roos 1987). The experiences of workers in the banking industry illustrate the 
effects of corporate mergers and downsizing for women's employment outcomes in service sectors.

\section{Job Exit Queues}

Reskin and Roos (1990) use queuing theory to explain broad patterns of occupational gender integration and feminization. They demonstrate how a dualqueuing process involving worker and employer rankings accounts for occupational sex and race distributions of workers. The two queuing processes are 1.) labor queues constructed by employers to rank workers and 2.) job queues constructed by workers to rank jobs (Reskin and Roos 1990, p.30). Labor queues and job queues interact to create unequal distributions of groups of workers across types of occupations or jobs. The larger context of institutionalized gender and race/ethnic inequality produces gendered labor queues based on these factors.

Queuing theorists have examined hierarchies of different groups of workers (whites, women, men and women of color) in the context of hiring (Reskin and Roos 1990). This perspective has not been applied to the process of losing a job or working during a corporate merger. This theoretical vantage point allows researchers to see how gender inequalities are maintained even when the organizational context is changing. In the context of corporate mergers, we argue that once a merger is announced, all workers must decide when to enter the "job exit queue." At the same time, the company is merging, not closing down completely - thus the employer needs workers to maintain business activities. Even so, differential treatment of workers based on gender and organizational location persists throughout the merger process. Queuing up to leave the company is a major concern for most workers. Relations to the job exit queue should be different for workers depending on their location in gender, class, race, and age hierarchies.

These structural locations and job exit queues present different problems for workers trying to plan for post-displacement employment in an insecure economy. Ruth Milkman's (1997) study of downsizing at a General Motors (GM) plant in the 1980s offers one example of how workers respond differently to economic restructuring and how they plan for the future. In Milkman's study, GM offered the workers a buyout package or the chance to wait and hope for a job with the new plant. Those workers who took the buyout package had better postdisplacement outcomes, they were younger and many became successfully selfemployed. The GM workers who remained on the job experienced a "painful uncertainty" about their future employment, and often expressed a loathing of GM specifically and manufacturing work in general.

\section{Job Loss, Mobility, and Gendered Processes}

The global restructuring of jobs undermines wages and job security for women, people of color, and those in peripheral sectors of the economy (Spalter-Roth and Deitch 1999, Browne et al. 2001). According to Cooper and 
Lewis, organizational restructuring can "exacerbate women's disadvantage in a variety of ways" including making it more difficult to monitor gender balance, affecting management functions and decisions differentially in those areas held predominately by women, and increasing the importance of networking and informal organizational structures from which women are often excluded (1999, p.42).

When jobs in an economic sector decline through mergers, or are shifted to other geographic areas, the consequences for workers are twofold. Roos and Gatta (1999) argue that industrial and regional restructuring increase the inequalities in wages and jobs, and contribute to the earnings gap between women and men. Similarly, McCall (2001) argues that restructuring increases the earnings gaps between high skilled and low skilled women (and men). Employers rank groups of potential workers into labor queues according to worker attractiveness to employer needs, and workers similarly rank potential jobs in job queues. The relative resources of employers and workers (especially workers who are women, people of color, or workers from low socioeconomic backgrounds) continue to reproduce patterns of job segregation and wage gaps during and after sector upheavals (Tienda et. al. 1987).

\section{Research Questions}

We are interested in the maintenance of patterns of inequality for women in female-dominated sectors of the economy even as these undergo economic restructuring. The merging and downsizing of a local bank organization presents a unique opportunity for us to examine the processes that push and pull workers as employers reconstruct job queues. How might these function in reverse: how do workers leave or transition from a downsized, merged work site? What evidence do we have of an exit queuing process that links to the gendered structures of banking, job loss, and severance packages?

\section{Methodology and Design}

In the current study, we situate larger economic patterns into the local frameworks of company mergers and buy-outs by focusing on the experiences of gender-segregated bank workers. By using a qualitative method, we offer a complex view of the merger process from the perspective of the employees undergoing the change. Statham outlines a qualitative approach to examine gender in work relationships that "focuses on the perspectives of those involved in a given situation, arguing that many realities exist" and in-depth interviewing enables us to map out "the often unexpected ways gender interacts with any social process" (1993, p. 112). She encourages this qualitative approach to gendered work that enhances the possibilities for uncovering misconceptions about specific jobs (and of variations in the experiences of women across different jobs) and facilitates the discovery of unexpected stressors on women workers (Statham 1993, p. 125). 


\section{Data Collection}

Our case study includes employees who worked for Bank Processing Solutions (BPS), a commercial bank subsidiary of a company owned by Local Bank (LB). Bank Processing Solutions employed approximately 650 people with eleven computer services centers in seven states. Corporate headquarters are in Midcity, a metropolitan area of approximately 200,000 residents. Several smaller data processing centers are located in surrounding areas and states. We also interviewed employees at one of these smaller remote centers at Smallcity (same state).

BPS and Local Bank are situated in the second largest city, one of three Metropolitan Statistical Areas in this Midwestern state. Prior to the economic downturn of 2001-2002, the state economy was about one third agriculture, with the remaining economic activities focused on government jobs, military, manufacturing, and service. The city unemployment rate was among the lowest in the nation (3.8 \% compared to a national rate of $6 \%$ ). The city proper has mostly light manufacturing, state government jobs, a substantial higher education employment sector, and a large service sector. Banking, insurance and investment companies make up the largest of the financial services industries in the city, and this sector comprises $5.7 \%$ of all jobs.

The data for this study derive from semi-structured interviews with 19 banking employees. We use a contextualist or holistic approach to describe and understand events, actions, and processes in the natural context in which they occur without attempting to generalize to a larger population. Our sampling deliberately includes those respondents who can be the richest sources of information in a specific context at the work site (Creswell 1994).

BPS is located in a feminized sector of the economy. Regrettably, we could not obtain the specific number of men and women in the company or in specific job titles, but we had informants and respondents who verified the feminized nature of the company. Key informants identified pockets of male dominated work and mixed gender work within BPS. Most of BPS'S employees are women, and most of the jobs are low-status, low skilled clerking and sorting jobs. However, the highest positions of power within the company were held by white men. Middle management jobs and skilled professional jobs were also male dominated. Low-level managers (first line supervisors) had an approximately even distribution of male and female workers. Therefore, our findings will be most richly applicable to the experiences of service workers in feminized sectors of the U.S. economy.

\section{Interviews}

Semi-structured interviews averaging 90 minutes in length were conducted with each respondent between June and October 2000. The questions covered employment history, workplace and family issues, and the impact of the merger and background demographic information. Most pertinent to the topic of this paper was a series of questions regarding the current job and future employment plans. 
Table I. Interview Questions

What do you like/dislike about your job?

How important is your work to you and why?

Do you think you will lose your job?

What are your greatest concerns about your job right now?

If you lost your job, how easy would it be to find another one that is comparable in terms of pay, benefits, skills, scheduling, etc.?)

While we were in the field, the company was sold a second time. The last few people we interviewed had stayed on with the new company, but most of the interviews took place during a time of the merger when the respondents were unsure about their job security and about the status of corporate ownership. As a result, we gain insights into the rolling process of the merger, but lack information on the worker's future employment outcomes.

\section{Sampling}

We recruited some of our 19 participants through a company e-mail request for volunteers, and others through referrals by employees or by an "insider" interviewer informant. Our goal was to broadly select people who held positions at different levels of the organizational hierarchy. Our respondents include middle and lower management, mid-range non-supervisory employees, and workers holding the lowest status positions in the company. Most of our respondents live in dual-earner households. We did not offer incentives, but offered to babysit for busy parents doing interviews. This offer to "trade time" was taken up by two women respondents.

We achieved targeted variation among differing positions within the occupational hierarchy, and we had both women and men in mid-level managerial positions. We were unable to interview any "top-upper" management individuals. One department head declined because he did not "have time;" the human resources director also declined. We have fewer men (5) than women (14) overall. Because of the small numbers of men and non-random sampling techniques, our conclusions about gender and class intersections are tentative and suggestive. We will know more about vulnerable workers in general, and specifically about low skilled women workers.

\section{Data Analysis}

All interviews were tape-recorded and transcribed. We coded interviews using Ethnograph 5.0 software. We constructed codes in stages, beginning with a wide net of data and coding within this net. Focused coding was used to concentrate on smaller pieces of themes. From this larger net of data, another stage of cod- 
Table II. Respondent name, sex, age, and organizational position

\begin{tabular}{lcll}
\hline Respondent Name & Sex & Age & Position \\
\hline Nell & F & 41 & Semi-autonomous \\
Marjorie & F & 44 & Manager \\
Tom & M & 44 & Manager \\
Madeleine & F & 51 & Semi-autonomous \\
Frank & M & 46 & Low Status/Skill \\
Jill & F & 35 & Low Status/Skill \\
Alice & F & 44 & Low Status/Skill \\
Annie & F & 51 & Manager \\
Barbara & F & 29 & Low Status/Skill \\
Heather & F & 56 & Low Status/Skill \\
Mark & M & 51 & Manager \\
Leon & M & 30 & Low Status/Skill \\
Patsy & F & 27 & Low Status/Skill \\
Victoria & F & 25 & Low Status/Skill \\
Jeannie & F & 37 & Manager \\
Justin & M & 38 & Semi-autonomous \\
Paula & F & 22 & Low Status/Skill \\
Jennifer & F & 46 & Manager \\
Donna & 38 & Semi-autonomous \\
\hline & & & \\
\hline
\end{tabular}

ing took place wherein the smallest segments of analysis were conceptualized (Lofland and Lofland 1995). We went through this coding process several times while we worked on manuscripts.

Initially, our analysis focused on finding themes across gender and organizational position. The importance of severance packages to most respondents was clear after the first few interviews. However, our understanding of how these packages fit into the "job exit queue" resulted after reading, coding, and writing. We specifically asked respondents about their plans for future employment and how they felt about the merger and changes in their current jobs. From these responses and discussions, the notion of a "job exit queue" developed as we learned more about who was still employed and also who had already left. From the perspective of many low-status workers, we learned about higher status workers and managers who left the company with generous severance packages as soon as the merger began. 
Table III. Gender, organizational position, and level of sex segregation

\begin{tabular}{lccl}
\hline & Men & Women & Occupational Sex Segregation \\
\hline Low status/skill & 2 & 7 & Female dominated \\
Semi-autonomous & 1 & 3 & Male dominated \\
Managers & 2 & 4 & Male dominated \\
$\quad$ Mid level and lower level) & & & (Lower level mixed gender) \\
Elite Managers & 0 & N/A & Male dominated \\
Total N=19 & & & \\
\hline
\end{tabular}

\section{Findings}

The most significant conclusion of our research is that job queues operate during the job exit process and are confounded by gender and job status. In this section, we reveal two major themes about worker relations to job exit queues. The themes include 1) how gendered labor queues are maintained in the merger process and 2) how severance packages contribute to gender inequality in the queuing process. In these major sections, we organize our findings by organizational position comparing men and women within the three major occupational groupings. First, we present evidence of job exit queues by analyzing respondents' perceptions of their jobs during and after the merger.

Second, we present an analysis of the severance package allocation process. Here we link this process to job searches and job exit queues. The significance of severance packages varied among women, as well as between gender groups. We find that severance packages are a mechanism through which gender and class (organizational location) inequalities are reproduced.

\section{Job Searches and Exit Queues}

Plans for future employment are indicators of employees' ranking of job exit queues and subsequent job opportunities. We asked respondents about their current job situation and their plans for future employment. During these discussions, respondents mentioned several factors that came into play regarding how they were planning for post-merger employment. These factors and strategies varied by gender and organizational location. Overall, women at all organization levels indicated concerns about finding comparable work. Some longterm women workers worried that experience would not be as important as educational credentials. Others noted age discrimination as a barrier to comparable employment. The few men we interviewed were more optimistic about using social networks to find comparable jobs. However, one low-status man reported several concerns (lack of education, age factors) that more resembled his women 
peers. These differences are evidence of varied relations to the job exit queue, which in turn have implications for post-displacement employment.

\section{The Queue for Managers and Semi-autonomous Workers}

We interviewed female and male managers and high-skilled programmers, analysts, and engineers (what we termed semi-autonomous workers) and asked for their plans and concerns about looking for a new job. Among midlevel managers and high skilled workers, we found our three male respondents set out distinctive themes about mobility and job searches as a result of downsizing. Because these are employees (male or female) who do not set the conditions of the sale and reorganization of the company, they chafe at the uncertainty, but interpret that against a theme of opportunity:

Mark: ... whether your job is eliminated or not, there's gonna come opportunity out of this change and the opportunity .... I've been here this long, I've survived many presidents, survived Viet Nam, I'll get through this. I'm just waiting for the opportunity.

In all cases, the male managers had a college education (at least a 2 year degree), which seemed to anchor their confidence, despite their lack of control over the corporate decision making. One manager noted that he is confident that "everything will work out" and that he can go some place else to make "six figures."

Female managers and technical coordinators had opportunities to look at the job disruption as an opportunity, as did male managers. Their job networks and job titles were working for them:

Marjorie: I've been contacted by one or two headhunters ... I somewhat expected it, but also my level of interest.... I'm not getting a lot of calls because I haven't put my name out there as looking. And you know even with this headhunter, I haven't really sent her a resume yet to start looking for work. Cause I'm really gonna wait and see.

However, not all women managers and technical workers embraced the merger as an opportunity. According to Nell, a high skilled technician:

Nell: ... I think that if I went to someplace else, I'd have to start back down here and then start trying to climb again, start earning that respect, and that reputation and everything, and I, I [laughs] I just really don't want to do that.

Men managers were more optimistic compared to their female counterparts. However, we did not interview any men managers with only a high school education, since all male managers had some college background.

Age and Education Confound the Queue

As a group these higher-status workers had some leverage for finding new jobs. However, they had concerns about age discrimination and the lack of formal 
educational credentials as potential barriers to post-merger employment. Both women and men in these mid level positions noted that their more senior status and wages in the company might be leveled by confounding factors such as age. A high-skilled semi-autonomous worker feared her age would negatively impact her job search:

Madeleine: And I have doubts that it will be easy for me to find a jobbecause of my age. ... I'm also 51 years old. And so they can hire someone that's 25 or 27 and pay them $\$ 20,000$ less than I make. Which makes sense to someone that's looking at the bottom dollar. So what do you do?

One of the woman managers, not yet seeking another job, framed that reluctance in terms of her past mobility in the company through seniority and experience, rather than formal education:

Marjorie: I mean just the last six years I've worked for BPS I didn't need a college degree to get anywhere up, you know within - I worked my way up from the bottom. So, I'm not sure that that would hold true today, and I was very lucky because I worked in a small bank where I got to learn all facets of banking and today that's fairly unique.

Managers and high-skilled workers had more resources and viewed the job exit queue with some reservations, but they also had educational credentials (in some cases) and experience, which would help them find new jobs. Educational degrees offered some comfort for men and women in these positions. Women managers who moved up the job ladder without educational credentials voiced concerns about translating their experience into comparable employment. Furthermore, these workers were unsure about age discrimination and feared making substantially less money in the future.

\section{Exiting from the Bottom: Low-status Workers}

In contrast to managers and high-skilled workers, low-skilled men and women were most concerned about their insecure relation to job exit queues. In this gendered sector of this local bank structure, we interviewed two of the few lower status males. Both were married and each contributed half or less of their total family income. Their precarious positions financially at home and on the job in the merger come through in their responses:

Leon: Right now, I'm in limbo. This is the longest I've ever worked in one place. I've felt more secure here than I have at any other job. ... I resent it [the merger], but this, I've been satisfied here. ... I feel like, Oh geeze, what am I gonna do now?

One of these male respondents concludes with a cynical view of the economic situation around him, in contrast to the managers and technical project coordinators cited above: 
Leon: I guess we should have expected something like this, with the way things are going in business. ... All the little guys are getting gobbled up, and it's the same in all, everywhere. I think if it keeps going like this there's gonna be 3 or 4 companies that own everything.

\section{Women Exiting at the Back of the Queues}

Many of the women in lower status positions responded to organizational changes and their job searches with broad confusion and reluctance to go out into the job market early. When asked about her future employment plans, Heather did not have any specific plans but noted she did not want to work in the banking industry any more after the merger. Heather worked for BPS for 25 years and with some college education she is less concerned about finding a job because she has fewer day-to-day financial pressures; her home is paid off and her husband is employed. But she is troubled about eventually finding comparable work because she would have to start over at the bottom and work her way back up again. Starting over was viewed negatively by many respondents, as they would be losing seniority. The notion of a difficult search for comparable work rang throughout the interviews when asked

Int: How easy would it be to find, to find another job?

Victoria: It'd probably be very hard.

Jill: I can flip burgers with the best of them. [Laughs] A comparable might be a little more difficult.

The lack of formal credentials also entered their deliberations:

Alice: Um that concerns me a lot because I haven't been in a school environment for 28 years. You know, and being able to go to school and take care of my family at the same time and do the job I'm doing now. And then, going out afterwards and finding a job.

These respondents recognize that formal credentialing and a restricting job market make them vulnerable, even with on-the-job experience. Their reluctance to enter the job exit queue was confounded by the ambiguity of severance packages, job schedules, or lack of formal education.

When asked about qualifications for their current positions, these low-status women were clear about the minimal set of requirements; the ability to "point and click," "interact with people well," "um, none" were typical responses. Some low-status workers told us that they were promised preferential treatment if they applied for jobs at the new company. However, they still perceived a lack of comparable low-status jobs with the new company, which prevented serious job searches within that new company. Low-status workers also indicated concerns about industry-wide merger waves and the resulting reduction in employment: 
Alice: One of the reasons I don't want to go back into the banking business is I'm afraid this is gonna happen again. Because it's happening everywhere. You how, we were just fortunate we were here this long without something like this happening.

Overall, the women in these low status positions remain in place, doing their assigned jobs out of loyalty, but often taking on additional tasks as other skilled workers leave ahead of them (Berdahl and Moore, 2002). Most are reluctant to "queue up" to leave during the downsizing and merger process, while voicing confusion and concern about the ability to improve their position when finally forced to leave. The company is able to benefit from having a "captive" work force during the downsizing process; routine activities continue while reluctant market entrants hang on for potential "severance" benefits. The likelihood of downward mobility on the way out of their current jobs keeps them out of the job exit queue and on the job as long as the company needs them.

Paula: I'm not really looking, and I would, you know, I'm really not too worried that it's gonna take more than my 3 months of being paid to find a new job-even if it's something, you how, I don't want to do right now ... till I find something better, you how, I'm just not too much in a hurry to look....

Low status women see themselves as continuing to cycle in a low wage, high turnover secondary labor market. Their job search strategies are ambiguous and not well thought out and begin at a disadvantage. Their ability to join an "exit queue" from this job to another is slowed by many complex work and family factors. These combine with a lack of meaningful severance and unknown termination dates to leave them "in place" longer than other workers.

\section{Maintaining Gendered Labor Queues}

During the merger, needs of the employer changed the labor queue, but preferences based on skill (and ultimately gender because of segregation) impacted their decisions about who would be laid off and when, if at all. BPS needed a workforce to maintain services, but we learned that entire groups of high status workers entered the job exit queue immediately following the merger announcement (senior level managers and accountants). Notification of termination and the allocation of severance benefits were not random occurrences, rather, they followed a pattern based on the status hierarchy within BPS. This pattern indirectly reflects a gendered labor queue, as women were concentrated in low-status positions and few women occupied higher status jobs within BPS. Even within the organizational hierarchy, differences between men and women emerged.

Many BPS workers told us they stayed on because they were invested in receiving severance. Severance benefits were not offered to all employees at the same time, as the benefits were tied to termination notices. In order to receive a 
package, the worker had to be laid off. Thus, the company could use severance as a way to maintain their work-force and lay off workers on an "as needed" basis. All of the workers we interviewed (except one) worked full-time for the company at the time of the interview.

Workers at all organization levels emphasized the importance of receiving a severance package, which had been promised in the initial merger with National Bank (NB) and was based on current salary and seniority with the company. Pinning down the rules of receiving severance compensation proved difficult for most workers, especially because our workers' subsidiary company was then sold off separately by National Bank.

For some employees, waiting for layoff notification was necessary in order for them to receive a severance benefits package offered to them by NB. NB's severance benefits policy stated that benefits are only granted if the employee receives a 60-day termination notice. The second sale did not include a well defined severance policy. Employees who quit were not eligible for severance pay from either company. Part of the ambiguity was not knowing if severance benefits would be granted by either company. There was no guarantee that the new company Regional Bank Processing Solutions (RBPS) would offer them any severance benefits at all. Because NB offered severance benefits, only employees laid off by NB would receive benefits.

Thus, most of our respondents worried at first about whether or not they would retain their jobs at all, and then with which company. If they did have a job with the new company, they worried about whether they would be treated fairly by the subsequent owners. For long-term employees especially, the issue of severance benefits had important effects on their perception of the situation. However, responses varied by position and gender regarding the significance of receiving a severance package. We also found evidence of variations among women, and between men and women workers. As we demonstrate, waiting for severance packages delayed these workers from entering the job exit queue in patterns that benefited the company and not the employees.

\section{Women's Severance and Gendered Exit Queues}

Women varied in their perceptions of the severance package process. Among low-status workers, short-term employees viewed the severance packages differently compared to long-term workers and those in higher positions. Women in management and skilled tech positions viewed severance packages as important too, but they were more concerned about knowing their termination dates so they could enter the job exit queue. In this section we contrast the perceptions of severance packages held by women in diverse organizational positions.

Some women with long job histories at the bank in low status positions viewed the package as an "opportunity" to go back to school, or enter a new industry. When we asked Heather about her future plans for employment (Age 56 Female, low skill/low status) she told us how she counted on the leeway a one year severance package would provide... 
If everything goes well and I get my severance package like I'm supposed to I may watch a couple of my grandsons. ... And I might volunteer more ... so right now with everything going on you just feel like you wanna rest your brain for a while and worry about it later. I might go work at Target, I don't know. I'm not really worried that I couldn't find something to do, but I just don't feel like thinking about office work.

Heather viewed severance as a form of economic security, and a year to figure out what to do next. She is also interested in doing something other than "office work." Another long-term low-skilled woman worker (Alice) voiced similar views of her severance package, which is "guaranteed" because she works at the Smallcity location, a work site that is being completely shut down. Alice is perhaps the most optimistic respondent in our study. Her situation is relatively unique, as she knows she will get her severance package, because she worked at the Smallcity center. Later in the interview Alice detailed her post-layoff plan to enroll in the local community college to become a medical transcriber. These two low-status women workers explicitly tied severance benefits to their future employment prospects. One woman has already talked with community college counselors and has a plan for upgrading skills that is dependent on the severance package.

Most short-term women in low-status jobs valued severance primarily to meet immediate financial needs. For example, Patsy says:

It would be a boost for my family if we got the severance and I went to Oregon and found another job and got paid from both jobs would be hunky dory.

Some women with young children reported that child care needs impacted how helpful severance would be. Short-term women workers are looking at a few weeks of severance, rather than several months or an entire year. These women did not link severance benefits to future job searches or employment and they voiced different concerns regarding entering the job exit queue compared to longterm women and men employees.

Semi-autonomous women workers also report concerns with severance packages. While Nell is not concerned about finding another job, the ambiguity surrounding termination did cause concern about having a stable source of income:

The not knowing [when her job would end] and the not being told is the scary thing. I said that I'd stay till the end but I think companies that, when the end comes they could go two, three weeks without a paycheck, and I can't do that. My kids and I depend on just my paycheck.

Madeleine, a woman business analyst, primarily worries about termination. Her concern is filtered through whether or not she receives a severance package, since a 60-day termination notice is required to get severance. According to Madeleine, getting a termination notice would be a clear indication to receive sever- 
ance and enter the job exit queue. The delay and constant ambiguity of termination and severance caused considerable concern for semi-autonomous women workers.

I mean cause those people ... that know that their jobs are gone, they seem more at ease than anybody over here. Because they know and they can go forward, or they know that they're gonna be in National Bank train/retrain, severance, whatever. But where we're sitting, we don't know that.

As a group, women managers expressed some concerns about their future employment prospects but also expressed confidence in the company's severance process that was not shared with the other groups of women. While they were waiting for termination notices too, they viewed the NB-BPS merger as on the whole a positive business-as-usual situation. As illustrated by Marjorie:

R: If I was not part of the sale, I could apply for the "retain and retrain" and certainly be eligible for the National Bank's severance.

Int: But you're not eligible for that because you're being sold to somebody else?

R: Right now I haven't been, until you're given a 60 day notice, but we certainly are open to apply for any jobs right now. We are part of National Bank, I mean as of the final agreement. So, we're open to apply for any of the jobs in the United States ... waiting and seeing. Really, to see if I have a position or not. I think if I'm not part of the sale, you'll see me very aggressively looking here or looking outside.

This woman has already been contacted by employers seeking to hire her. Overall, women managers viewed the severance packages as generous, and some viewed them as safety nets in case they could not get other jobs. Jeannie, the only female manager with small children, is concerned about family finances and told us she "has to work," and at least one of the older woman managers also talked about changing careers, or finding work that she enjoyed.

Among the women workers, two differing approaches to severance benefits emerged as critical issues in the merger process. The low status workers with seniority and the women managers with few formal educational resources were likely to look at their months of severance as providing needed support during their search for a new position, but were concerned that the severance packages were inadequate for retraining or improving their current relation to the job queue. Only one of these workers was enthusiastic about the potential to use the severance package during re-training as a transcriptionist (which requires less than one year of community college training). In contrast, women managers and technical workers focused primarily on severance as a financial tool, but felt no need to look to the severance package for improving their education or qualifications for new jobs. 


\section{Men and Severance}

In contrast to women employees, men reported fewer concerns regarding the severance package process. One male manager mentioned severance packages only in the context of fairness to employees. He believed that severance packages were appropriate and did not have any worries about not getting his severance. Perhaps this is due in part to his confidence in finding another job, if that is required. The other male manager did not mention severance at all during the interview process. This respondent elaborates on how the merger process has played out ...

Int: Do you think you've been treated well [through the merger]?

Tom: Sure.

Tom is less concerned about losing his job and his possibility for obtaining future employment. Justin, our only semi-autonomous male worker (engineer), framed the merger in similar terms. We interviewed Justin after the second sale, and he was already working in a new job while staying on with the new company as an on-call consultant. When asked about his experience and thoughts during the merger process, Justin notes:

... there was the merger and everything was just kind of up in the air for so long. And my job at BPS was guaranteed - they had told me I would stay on with the new company. So I wasn't too worried about losing my job. There at the end I was hoping that I would have been on the severance package, so I could've got that and then taken another job too, but it didn't work that way.

Justin did not receive his severance package. This fact does not emerge as particularly problematic, as he was intensely recruited by an outside company during the merger process.

Our responses from two low-skilled male workers focused on corporate responsibility. Leon, a low-status male worker, told us:

I think it's their responsibility, the company, when you put people out on the street if you're responsible you'll try to give them the chance to succeed. Even though you don't need them anymore. ... We didn't do anything negative to lose our jobs - just because of their business decisions. I think to be responsible they should help out all the employees who lose their jobs. You know training, severance, and all that. I think it's important.

Leon notes severance is an important way to fulfill a moral obligation of the company to its workers. He does not elaborate on his particular situation, or what severance benefits mean to him and his family. The other low-status male worker was working at the remote center and was guaranteed to receive severance. He also thought severance benefits were appropriate, but he did not bring up severance as a critical resource for the transition or postmerger job search. 
We found that workers who counted on their severance package were generally more vulnerable and perceived barriers to finding comparable work. For some workers, severance pay and benefits are critical to managing the merger transition, or getting through the job exit queue and into another job. We found evidence that the level of importance, and how severance benefits are perceived, varied among women and across gender lines. Importantly, long-term low-status women workers viewed severance as a cushion and a job search resource. Shorter-term low-status workers tended to view severance as a "boost" or a short term cash bonus to meet immediate needs such as child care costs. Like the low-status women workers, women managers did express uncertainty regarding finding future comparable employment, and some counted on a long severance period to help them secure future employment. Simultaneously, high-status or high-skilled women as a group did not count on severance packages in the same way. They had more leverage in the labor market, and while they may be contemplating changing occupations, they express some confidence in transferring their skills, as evidenced by the woman who has already been contacted by headhunters. Women who "banked on their package" were aware of their vulnerability and voiced concerns about future employment.

The most notable difference between the men and women workers is how they link job exit queues and future employment to severance packages. Severance was less salient for men at all levels of employment. Men managers perceived few obstacles to finding continuing parallel employment when and if they lost their jobs. The engineer was already recruited to a better paying job with better working conditions. Losing severance was not crucial to his decision to take a new position before being terminated. The two low status men talked about severance packages as a corporate obligation, but neither expressed worries about receiving these, even though only one had a guaranteed package. Female managers and technical workers voiced more concerns about actually receiving the severance, but again did not link the severance package to concerns or strategies about future employment. The most vulnerable of our respondents, low status women workers and midlevel women managers with few educational credentials, raised the issue of severance and its inability to bridge them through the merger to jobs with similar benefits or pay. For them, severance would only serve as a cushion of financial support until they took other, less desired, jobs. Only one exception to this latter group saw her severance as an opportunity for one year of community college training.

\section{Discussion and Conclusions}

In this gendered banking industry, most women workers with multiple barriers (age, lack of formal education, child care issues) are reluctant to re-enter a competitive and restrictive job market. In this family-owned bank, women had worked into greater advantages through longevity and loyalty. They recognize 
that they are unlikely to find similar economic or social benefits at other jobs that do not hold loyalty to them or other employees. And so they remain at the back of the "queue" of those who will leave. They take on the tasks of those who leave ahead of them, and struggle with ambiguous plans in the face of ambiguous termination dates and severance promises.

The highest status managers in the company, those who knew the time schedules for the merger and downsizing, were unavailable to us for interviews, often because they had already left the company and were working for other banks or corporations. Among the formally-credentialed middle level managers and technical coordinators, the prospect of moving on to a new job was linked to opportunities, "head hunters," and making new priorities. These included all male interviewees and both male and female technical workers.

We found important similarities between the mostly male auto manufacturing workers in Milkman's study (1997) and these mostly female workers in the banking industry. First, severance packages were used in both cases to manage the workforce. Milkman's buyout takers tended to fare better after the merger compared to other workers. Furthermore, women and younger workers were more likely to take the buyout packages, while older (more senior) workers waited to see if they could remain employed by GM. In the current study, severance packages were used to manage the workforce, albeit in a different manner. Workers in male dominated parts of the company (upper management, skilled tech workers) were given termination notices and severance packages soon after the merger was announced. Most of the workforce (low-status women workers) did not get their severance packages, or were holding out hoping to get them during the several months of merger transitions. Furthermore, in our current study more senior women workers stayed on waiting for the severance package, thus the company retained experienced workers as well, but not because they were expecting to stay employed.

Our interviews with female middle managers expand on the findings of Reskin and Roos (1990) in their summary across many women managers in gender-segregated work settings. We also find these women middle managers are isolated (at the Smallcity center) and/or gained their positions through longevity and loyalty to the company. We identify important reinforcements of the gender segregated nature of the larger labor market that operate during a period of merging and downsizing. Reluctant to move into a competitive market that uses barriers such as formal education and age to sift out new applicants, they remain in their current jobs as long as possible with hopes of severance packages and a longer incumbency in higher status or better rewarded positions. Unlike credentialed managers, they fully expect downward job trajectories, and so they linger.

In many ways, both women and men workers in lower status positions (imaging clerks, dispatchers, etc.) parallel the concerns of "loyal" noncredentialed, women managers. They, too, know that their prospects are limited by their lack of formal education and the limited jobs in the geographic region. They, too, stay "in place" as long as possible because their prospects 
are limited and they will be separated from a "family run" business that had extended better benefits than they will find at national chains. Their less flexible work schedules, greater family responsibilities (due to younger family demographics) and more ambiguous communications from the company about termination dates and severance packages make them particularly vulnerable.

To the benefit of the company, these workers stay at the back of queues of those who will eventually leave the company voluntarily, or who will be terminated. They are hoping that loyalty and a few more months on the job might improve severance packages or will delay entry into a competitive, non-familybased corporate job market. The bank transforms its low-wage workers into a temporary work force who will maintain routine tasks and/or take on the tasks of former workers who already moved into the job search queue. This is particularly problematic for women.

These workers, men and women in lower status positions, and noncredentialed women in middle management, are backed up in the queue for leaving a downsizing company. Even they predict that their linkage back into new employment will be difficult and at a cost in pay, benefits, and flexibility to meet family responsibilities. We find that McCall's quantitative analyses (2001) of increasing differentiation among women workers, even within sectors, are richly demonstrated in our respondents' approaches to searching for new jobs. Our study is limited in that we do not know the actual employment outcomes for these women seeking new jobs, but their "positions" in the queues for leaving their current work site are quite differentiated.

Our research contributes a new site for analysis in queuing theory: the departure patterns of women and men across different positions and with different credentials in a gendered job sector. In an economy of increasing structural "adjustments, " the point of departure and timing of departure is as important as the point of entry in maintaining or increasing the wage and job gaps between and among women and men. Being backed up in the queue for leaving may link directly to being at the back of the queue for new jobs as well. When "loyalty" and ambiguous severance promises allow companies to delay the exit of those workers who can maintain their routine operations, those workers will be backed up in queue and disadvantaged in their search for a new job. The pivotal role of severance packages emerged during the course of our interviews and should be further researched as a flexible tool of economic control for the company. We argue that exiting a job creates a queue as well, and that inequality and stratification processes will be an important component of understanding these patterns of worker job disruptions in the future. 


\section{Acknowledgments}

The authors would like to thank Brooke D. Thaden for her invaluable field research and interviewing contributions to the data used for this study. We would also like to thank Kris Paap and anonymous reviewers for Equal Opportunities International for insightful and helpful comments on the project and the paper. 


\section{References}

Berdahl, T., \& Moore, H. (2002), "Deskilling and the Merger Process: Losing Your Job Before a 'Pink Slip' is Ever Written," presented at the Midwest Sociological Society Meetings, March 2002, Chicago, Illinois

Bielby, W. T., \& Baron, J. N. (1 986), "Men and Women at Work: Sex Segregation and Statistical Discrimination," American Journal of Sociology, vol. 91, pp. 759-799.

Browne, I., Hewitt, C., Tigges, L., \& Green, G. (2001), “Why Does Job Segregation Lead to Wage Inequality Among African Americans? Person, Place, Sector, or Skills?," Social Science Research, vol. 30, pp. 473-795.

Burke, R.J., \& Greenglass, E. (2001), “Hospital Restructuring and Psychological Burn Out in Nursing Staff," Equal Opportunities International, vol. 20, pp. 61-71.

Cooper, C. L., \& Lewis, S. (1999), "Gender and the Changing Nature of Work," in: Powell, G. (ed.) Gender and Work, Sage Publications.

Creswell, J. W. (1994), Research Design: Qualitative and Quantitative Approaches, Sage Publications.

Harrison, B., \& Bluestone, B. (1988), The Great U-turn: Corporate Restructuring and the Polarizing of America, Basic Books, New York.

Lofland, J., \& Lofland, L. (1995), Analyzing Social Settings: A Guide to Qualitative Observation and Analysis, Wadsworth Publishing Company, Belmont.

McCall, L. (2001), Gender, Class and Race in the New Economy, Routledge, New York..

Milkman, Ruth (1997) Farewell to the Factory, University of California Press, Berkeley.

Padavic, I., \& Reskin, B. (2002), Women and Men at Work, Pine Forge Press, Thousand Oaks.

Reskin, B., \& Roos, P. (1990), Job Queues, Gender Queues: Explaining Women 's Inroads into Male Occupations, Temple University Press, Philadelphia.

Reskin, B., \& Roos, P. (1987), "Status Hierarchies and Sex Segregation," in C. Bose and G. Spitze (eds.), Ingredients for Women's Employment Policy, SUNY Press, New York.

Roos, P., \& Gatta, M. (1999), “The Gender Gap in Earnings: Trends, Explanations and Prospects," in: Powell (ed.) Gender and Work, Sage Publications.

Spalter-Roth, R., \& Deitch, C. (1999), “I Don't Feel Right-Sized: I Feel Out of work sized," Work and Occupations, vol. 26, pp. 446-482.

Statham, A. (1993), "Examining Gender in Organizational Relationships and Technological Change," in: Long, B., \& Kahn, S. (eds.) Women, Work and Coping: A Multidisciplinary Approach to Workplace Stress, McGill-Queen's Press. 
Stover, D. (1996), "The Stratification of Women Within Organizations," in: Dubeck, P., \& Borman, K. (eds.) Women and Work, Rutgers University Press.

Tienda, M., Smith, S., \& Ortiz, V. (1987), “Industrial Restructuring, Gender Segregation, and Sex Differences in Earnings," American Sociological Review, vol. 52, pp. 195-210.

Wallace, M. (1998), "Downsizing the American Dream: Work and Family at Century's End," in: Vannoy, D., \& Dubeck, P. (eds.) Challenges for Work and Family in the Twenty-First Century, Aldine de Gruyter, New York. 